\title{
ЗАХИСТ МІОКАРДА ПРИ ОПЕРАЦІЯХ НА ВІДКРИТОМУ СЕРЦ
}

\author{
Шликов В. В., доц., к.т.н. \\ v.shlykov@kpi.ua \\ Факультет біомедичної інженерії \\ Національний технічний університет \\ «Київський політехнічний інститут імені Ігоря Сікорського» \\ м. Київ, Україна
}

\begin{abstract}
Реферат - Метод гіпотермічного захисту міокарда займає важливе місце при корекиії неускладнених пороків серия, а пригнічення метаболізму і зниження потреб міокарда в кисні при низькій температурі є основним кардіопротекторним фактором, який забезпечує захист міокарда в умовах штучного кровообігу. У даній статті описані існуючі методи захисту міокарда та інтегральні показники для повноиінного захисту міокарда при операціях на відкритому сериі. Представлені температурні характеристики міокарда і фактори, які визначають ступінь ішемічних ушкоджень міокарда при гіпотермії серия. Запропоновано спосіб неінвазивного вимірювання температури серия в умовах штучного кровообігу. Для оцінки даних зміни температури на поверхні міокарда в умовах штучного кровообігу пропонується використовувати термографічні камери, які працюють у діапазоні частот 7,5-13 мкм і мають температурну чутливість не нижче $0,5^{\circ} \mathrm{C}$.
\end{abstract}

Ключові слова - захист міокарда, гіпотермія, итучний кровообіг, термографія, розподіл температури.

\section{І. Вступ}

Більшість із сучасних інтраопераційних методик захисту міокарда, які включають кров'яну кардіоплегію, забезпечують безпечну і ефективну протекцію міокарда під час різних операцій на відкритому серці [1]. При цьому, усі методики, що засновані на застосуванні кардіоплегічній зупинці серця та інші, що використовуються в цей час, піддають серце позбавленню коронарного кровообігу. Розвиток технічних засобів і поява нових технологій дає можливість оперувати пацієнтів із групи підвищеного ризику, а також визначати інтегральні показники захисту міокарда при операціях на відкритому серці безпосередньо в умовах штучного кровообігу.

Метою дослідження $є$ обгрунтування ефективності застосування тепловізійних методів вимірювання температури міокарда в умовах штучного кровообігу в якості одного 3 важливих інтегральних показників повноцінності захисту міокарда при операціях на відкритому серці.

\section{II. Аналіз існуючих методів захисту міокарда}

Велике значення при операціях на відкритому серці має оцінка адекватності захисту міокарда при кардіоплегії. Аналіз експериментальних і клінічних даних показав необхідність застосування спеціальних заходів захисту міокарда при кардіохірургічних втручаннях для виключення ішемічних і реперфузійних ушкодженнях [2]. Необхідно також враховувати особливості застосування штучного кровообігу (ШК). Існуючі в цей час різні способи кардіоплегії (КП) дуже відрізняються друг від друга, що обумовлює відсутність їх загальноприйнятої класифікації. Однак для аналізу існуючих методів захисту міокарда можна використовувати запропоновану Л. С. Локшіним систематизацію методик кардіоплегії [3], яка найбільше повно враховує патофізіологічні та методичні особливості:

- по механізму впливу на міокард (ішемічна, штучна фібриляція, холодова, фармакологічна);

- по способу застосування КП розчину (зовнішня, перфузійна);

- по основному складу КП розчину (безкровна, кров'яна);

- по місцю нагнітання КП розчину (антеградна, ретроградна, поєднана);

- по вмісту кисню в КП розчині (з оксигенацією, без оксигенації);

- по температурному режиму КП розчину (гіпотермічна, теплувата при $28-30^{\circ} \mathrm{C}$, нормотермічна);

- по вмісту в КП розчині біологічно активних речовин (з використанням, без використання);

- за часом проведення КП (безперервна, періодична). 
В останні роки при операціях на відкритому серці застосовується перфузійна кардіоплегія 3 використанням аутокрові хворого. Застосування кров'яної кардіоплегії (КК) обумовлене великою кисневою і буферною ємністю, а також наявністю колоідно-онкотичного тиску [4].

При подачі КП розчину в систему ШК необхідно контролювати тиск у системі, оскільки збільшення тиску більш 100 мм рт.ст. може викликати набряк міокарда і травму ендотелію коронарних артерій, а зменшення тиску менш 80 мм рт.ст. не забезпечує адекватної доставки КП розчину. При цьому, об'ємна швидкість подачі КП розчину може коливатися в широких межах, становлячи у дорослого пацієнта до 10 \% від об'ємної швидкості перфузії ( при гіпертрофованому міокарді).

Ортоградна кардіоплегія може бути неефективною у хворих ішемічною хворобою серця внаслідок субтотальних або повних стенозів коронарних артерій, що обумовлене нерівномірним розподілом КП розчину між різними ділянками міокарда. При такій ситуації найбільш виправданої є ретроградна кардіоплегія, при якій КП розчин уводять у коронарний синус або в праве передсердя (при перетисненій легеневій артерії). При цьому тривалість подачі КП розчину може коливатися в широких межах, починаючи від дробової подачі КП розчину з різними інтервалами часу до постійної (безперервної) кардіоплегії протягом усього періоду стискання аорти. Необхідно також контролювати тиск у додатковому каналі в катетері для коронарного синуса, яке не повинне перевищувати 40-50 мм рт.ст.

У кардіохірургії про якість захисту міокарда зазвичай судять на підставі застосування і дозування інотропної медикаментозної підтримки, а також по процедурі використання допоміжного кровообігу [5]. Однак ці показники можуть залежати від вихідної скоротності міокарда і якості хірургічної корекції захворювання серця. Інформативними маркерами, які вірогідно свідчать про якість КП, є біохімічні параметри крові, яка береться з коронарного синуса: $\mathrm{pH}$, лактат і інші показники кислотно-основної рівноваги. У тому числі, маркером ушкодження міокарда $€$ визначення рівня креатинфосфокінази та ії міокардіальної фракції. Застосовується також методика визначення $\mathrm{pH}$ міокарда за допомогою контактного датчика, способи визначення тропоніна-I, міоглобіну і ряду інших маркерів ушкодження міокарда, які $\epsilon$ одними із самих чутливих і специфічних маркерів ушкодження міокардіальної тканини.
Інтегральним показником повноцінності захисту міокарда при операціях на відкритому серці є електрокардіографічна картина відновлення серцевої діяльності під час реперфузії (наявність або відсутність фібриляції, ішемічні зміни, порушення ритму, провідності і т. п.). Однак патологічні зміни, які визначаються на ЕКГ, не завжди пов'язані з ефективністю захисту міокарда. Для об'єктивної оцінки захисту міокарда відносно широко застосовується визначення температури міокарда за допомогою голчастого термоелектрода. Однак мозаїчність температури різних відділів серця ускладнює одержання інтегрального уявлення про ефективність захисту за допомогою такого методу вимірювання температури.

\section{III. Стратегія міокардіальної протекції}

Стратегія міокардіальної протекції при операціях на відкритому серці опирається на розуміння фізіології серця і механізмів споживання енергії серцевим м'язом. Тому, механізми захисту міокарда засновані на підтримці повноцінної функції серця, що пов'язане із забезпеченням спеціальних умов для постійного і адекватного постачання його киснем. У нормі кровообіг у міокарді контролюється ауторегуляцією, яка підтримує баланс між рівнем кровотоку і потребами міокарда у кисні.

Для підтримки функції серця в природніх умовах функціонування потрібна безперервна доставка кисню. Споживання кисню міокардом залежить від інтенсивності роботи, яка здійснюється серцем. У нормі працюючий міокард шлуночка споживає 8 мол кисню на 100 грам маси міокарда у хвилину. В умовах порожнього серця, що продовжує битися, споживання знижується до 5.6 мол кисню на 100 грам міокарда. В умовах калієвої зупинки серця споживання становить 1.1 мол кисню на 100 грам міокарда. Охолодження міокарда дає додаткове зниження до 0.3 мол кисню на 100 грам міокарда (Buckberg і ін., 1977) [6].

В умовах периферичної коронарної перфузії необхідно контролювати трансмуральний градієнт тиску, який являє собою різницю між діастолічним тиском в аорті та кінцеводіастолічним тиском усередині шлуночків. При цьому, доставка кисню може бути недостатньої через зниження перфузійного тиску внаслідок системної гіпотензії або патології коронарних артерій, а також внаслідок підвищення кінцево-діастолічного тиску в шлуночку (аортальний стеноз, фібриляція шлуночків або розтягання шлуночку). 
Під час штучного кровообігу (ШК) серце позбавлене більшості регулюючих факторів. Кров надходить із системи ШК в артеріальну систему по канюлі у висхідній аорті, а в проксимальну частину аорти та коронарні артерії розподіляється ретроградно. Під час повного ШК збільшується інтраміокардіальна напруга, а також трансмуральний і субендокардіальний судинний опір, що приводить до зменшення припливу крові до субендокардіального шару. Найбільш виражені ці явища при гіпотермії серця, що порушує кисневий баланс "доставка / споживання" кисню в міокарді.

Для хворих ішемічною хворобою серця спроба корекції гіпотензї адренергічними препаратами збільшує постнавантаження на міокард, і тим самим збільшує ішемію. При цьому в процесі тривалого ШК можливо утворення мікроемболів різного генезу, які порушують мікроциркуляції в міокарді. Факторами, які визначають ступінь ішемічних ушкоджень міокарда, є: тривалість стискання аорти, виразність колатерального кровотоку, дефіцит споживаного міокардом кисню та умови, що передують ішемії. Згідно літературним даним (Gravlee G.P. et al., 2000) [7] ризик ішемічного ушкодження міокарда зростає пропорційно тривалості ШК. Встановлено, що необоротні зміни в міокарді наступають через 20-30 хв. коронарної оклюзії працюючого серця, у той час як для зупиненого серця аналогічний період глобальної ішемії міокарда приводить тільки до його функціональної депресії без некрозів тканини.

В ішемічні ушкодження міокарда, поряд 3 міоцитами, втягується ендотелій судин, який бере участь у загальному імуно-запальній відповіді організму на ШК. Клітинний набряк тканин приводить до порушення секреції, що відіграє важливу роль у збільшенні резистентності коронарних судин міокарда при реперфузії. Особливо чутливий до ішемії міокард хворих із хронічною серцевою недостатністю, пацієнтів 3 пороками серця і нестабільною гемодинамікою. Для кардіохірургічних хворих наявність гіпертрофії міокарда та уражень коронарних артерій у результаті вихідного патологічного процесу підвищують його чутливість до ішемічних i реперфузійних ушкоджень під час ШК.

Тому, останні дослідження були спрямовані на збільшення припустимого періоду аноксії міокарда, використання гіпотермії та інших різних методів КП, визначення інтегральних пока- зників повноцінності захисту міокарда в умовах ШК, що дозволяє значно збільшити безпечний час стискання аорти і захистити серце від факторів ішемічних ушкоджень міокарда.

\section{IV. Метод гіпотермії міокарда}

У зупиненому серці споживання кисню i енергії значно знижується та визначається тільки рівнем базального клітинного метаболізму. Рівень споживання енергії може бути додатково знижений завдяки зниженню температури серця [8]. Споживання кисню при $37^{\circ} \mathrm{C}$ (і асистоліі) становить 1 мол у хв. на 100 г міокарда, знижується при $22^{\circ} \mathrm{C}$ до 0,3 мол, а при $15^{\circ} \mathrm{C}$ - знижується до 0,27 мол на 100 г міокарда. При температурі охолодження $22^{\circ} \mathrm{C}$ cepце, що б'ється, споживає приблизно 2 мол кисню у хвилину на 100 г своєї маси, при тому що працююче серце при зниженій температурі споживає в 2-3 рази більше кисню, ніж при нормотермії. Зниження температури $337^{\circ} \mathrm{C}$ до $4^{\circ} \mathrm{C}$ у комбінації з діастолічною зупинкою $\mathrm{i}$ декомпресією шлуночків дозволяє зменшити споживання кисню міокардом (MVO2) приблизно на 97 \%, тобто від значення 1,10 мол на 100 г/хв. до 0,13 мол на 100 г/хв. У зупиненому серці MVO2 зменшується на $50 \%$ при зниженні температури на кожні $10^{\circ} \mathrm{C}$. Отже, гіпотермія є одним з важливих елементів захисту міокарда, який повинен мати чітке клінічне призначення при проведенні кардіоплегії.

За інших рівних умов, періодична перфузія серця кров'ю охолодженої до $20^{\circ} \mathrm{C}$ протягом 2-х годин не захищає серце від ушкоджень у відмінності від крові, що містить компоненти кардіоплегії [9]. Крім того, при виключені серця із кровообігу на 1 годину, локальне зниження температури міокарда до $14-16^{\circ} \mathrm{C}$ меншою мірою захищає його, ніж однократне введення кардіоплегічного розчину при середній температурі міокарда $26^{\circ} \mathrm{C}$. При температурах $10^{\circ} \mathrm{C}$ и нижче припиняє знижуватися рівень глікогену в ішемізованих серцях, так само як і в перфузованих. Необхідність і безпека зниження температури нижче цього рівня $\epsilon$ не доведеною для клінічних умов ШК, тим більше, що вона швидко підвищується до 10$12^{\circ} \mathrm{C}$ завдяки колатеральному кровотоку і зігріванню під дією навколишнього середовища. Вважається, що коливання температури поблизу значень $10-12^{\circ} \mathrm{C} \epsilon$ найбільш бажаними для умов холодової кардіоплегії. На думку багатьох авторів, гіпотермія міокарда $22^{\circ} \mathrm{C}$ забезпечує відносно безпечне перетискання аорти протягом 45-60 хв. 
$\mathrm{T},{ }^{\circ} \mathrm{C}$

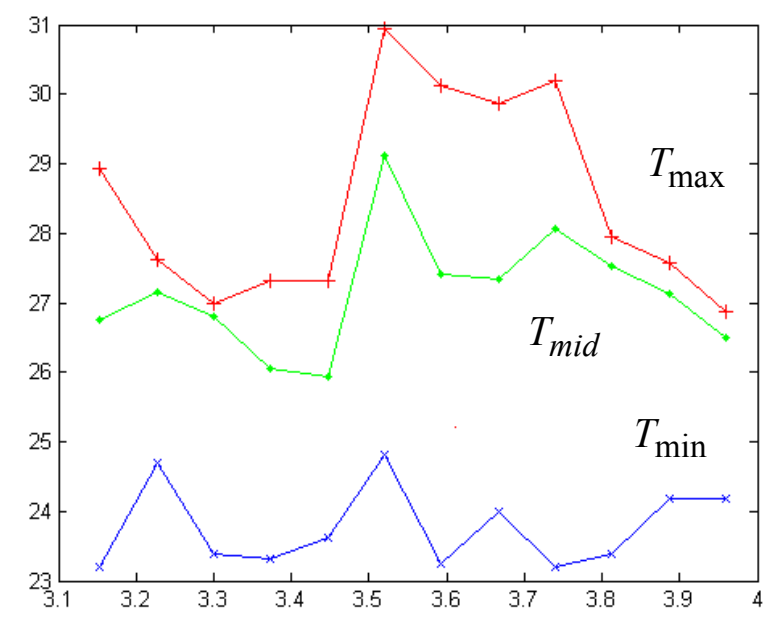

a)

$\mathrm{t}$, год

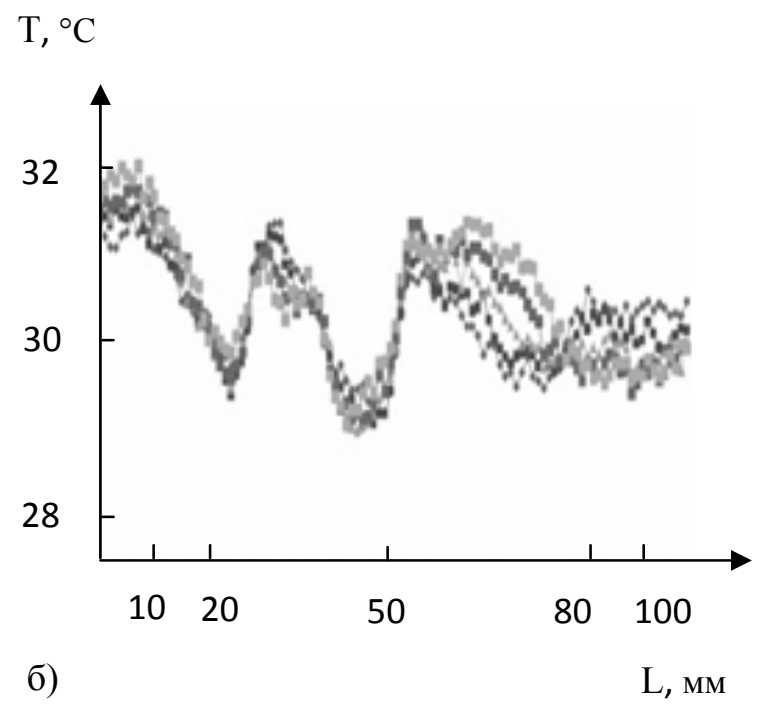

Puc. 1. Зміна максимальної $T_{\max }(t)$ і мінімальної $T_{\min }(t)$ температури в часі в умовах ШК: а) під час гіпотермії серця, б) під час гіпертермії серця

Для зручності роботи здійснюється введення в порожнину перикарда холодного $\left(2-4^{\circ} \mathrm{C}\right)$ фізіологічного розчину або обкладання серця "крижаною крихтою". Однак, застосування зовнішньої локальної гіпотермії міокарда недостатньо ефективно для захисту міокарда, і в хірургії вона застосовується тільки в комбінації з гіпотермічною інтракоронарною перфузією для досягнення більшої інтенсивності та рівномірності охолодження серця. Крім того, використання "крижаної крихти" викликає контактне ушкодження міокарда у вигляді мікроскопічних некрозів, у тому числі часті парези діафрагмального нерва.

В умовах глибокої гіпотермії, коли серце охолоджується холодним перфузатом і зовні- шньо, обкладання серця "крижаною крихтою" застосовується в хірургії дитячого віку при зупинці серця в умовах ШК. Цей метод поліпшує умови хірургічної роботи, але супроводжується більшою кількістю міокардіальних некрозів у порівнянні з коронарною перфузією.

Таким чином, гіпотермічний захист міокарда займає важливе місце при корекції неускладнених пороків серця 3 періодом оклюзії аорти від 45 до 90 хв., а пригнічення метаболізму і зниження потреб міокарда в кисні при низькій температурі $\epsilon$ основним кардіопротекторним фактором, який забезпечує захист міокарда в умовах ШК.

\section{V. Результати дослідження температури серця}

Для оцінки даних зміни температури на поверхні міокарда в умовах штучного кровообігу можна використовувати тепловізори Flir i7 i Thermo Cam E300, які працюють у діапазоні частот 7,5-13 мкм і мають температурну чутливість $0,5^{\circ} \mathrm{C}$ и $0,1^{\circ} \mathrm{C}$, відповідно. Послідовність зображень і відеокадрів в інфрачервоному спектрі, що реєструється з використанням тепловізорів, дозволяє оцінити динаміку розподілу температури в міокарді:

- мінімальну i максимальну температуру міокарда, що дозволяє оцінити неоднорідності розподілу температури на поверхні серця;

- швидкість зміни температури під час гіпотермії серця, що дозволяє побічно оцінити стан коронарних судин;

- температурне прискорення, яке дозволяє оцінити динаміку зміни температури в процесі охолодження і зігрівання серця, відповідно.

Метод неінвазивного контролю температури міокарда представляє набір чисельних способів аналізу термографічних зображень, у тому числі: метод тепловізійної діагностики із застосуванням оптичної системи стабілізації термограмм [10], метод безперервної обробки відеоряду з послідовності термографічних зображень [11], метод обчислення швидкості поширення тепла в міокарді при його теплопередачі від коронарних судин [12].

Значення температур на поверхні міокарда, які обчислені для термографічних зображень під час кардіохірургічної операції аортокоронарного шунтування, представлено на рисунку $1(a, \sigma)$.

Зміна максимальної $T_{\max }(t)$ і мінімальної $T_{\min }(t)$ температури в часі в умовах штучного кровообігу показує нерівномірність розподілу 
температури в різних відділах серця. Крім того, температурні залежності показують нерівномірне зниження і підвищення температури різних ділянок міокарда при охолодженні та зігріванні серця, відповідно.

Значення температур на поверхні міокарда, які реєструються для охолодженого до $24^{\circ} \mathrm{C}$ i зупиненого серця в умовах штучного кровообігу, представлено на рисунку 2 (a, б).

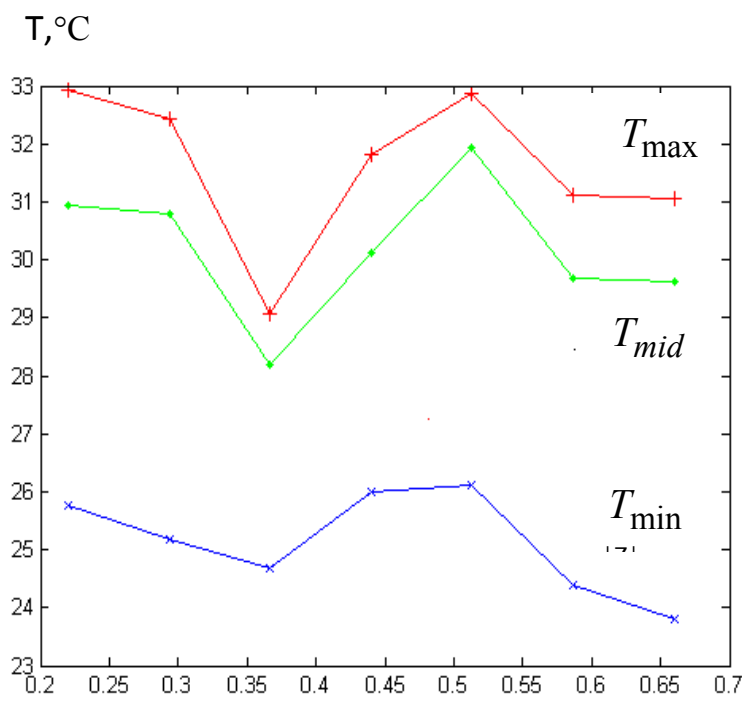

a)

t, год

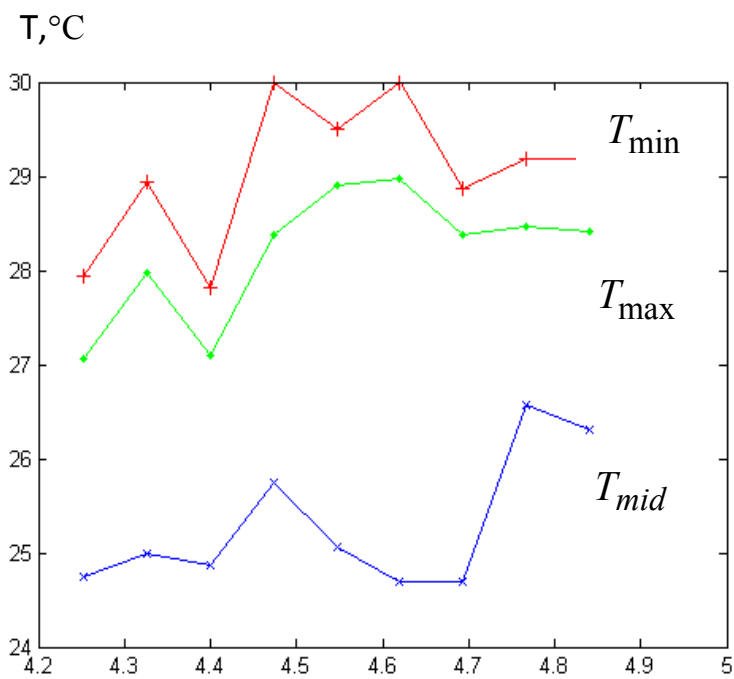

б)

$\mathrm{t}$, год

Рис. 2. Зміна температури міокарда для зупиненого серця в умовах ШК:

a) максимальна $T_{\max }(t)$ і мінімальна $T_{\min }(t)$ температура в часі, б) температура на поверхні розміром $L$ до 100 мм у декількох досліджуваних ділянках міокарда

На ділянках 3 відкритої поверхні міокарда розміром L до 100 мм різниця температур може досягати $6-7^{\circ} \mathrm{C}$ від середнього значення температури $T_{\text {mid }}(t)$. Коливання температур на поверхні міокарда в досліджуваних ділянках, які мають певну періодичну закономірність зміни температури від $28,4^{\circ} \mathrm{C}$ у мінімумі до $32,1^{\circ} \mathrm{C}$ у максимумі, що обумовлюється поширенням електричного збудження і механічного скорочення м'язів серця.

У результаті дослідження нерівномірної зміни температури на поверхні міокарда можна виділити області, у яких усереднені коливання температури $T_{\text {mid }}(t)$ знаходяться у діапазоні $25-32^{\circ} \mathrm{C}$ за весь період операції та області зі зміною температури не більш $0,5^{\circ} \mathrm{C}$ за період часу 5 хв. при підтримці необхідної температури серця в умовах ШК.

Отже, розробка методів вимірювання температури, які забезпечують безперервний контроль температури різних відділів серця в умовах ШК без ушкодження міокарда, є одним 3 важливих способів об'єктивної оцінки температурного режиму КП. У комбінації з методиками захисту міокарда, які застосовуються в кардіохірургії, неінвазивний метод вимірювання температури дає важливий інтегральний показник повноцінності захисту міокарда при операціях на відкритому серці в умовах ШК.

\section{VI. Висновки}

Отримані дані вказують на значні коливання температур на поверхні міокарда в досліджуваних ділянках. Таким чином, практичне використання методів гіпотермії та інших різних методів кардіоплегії вимагає визначення інтегральних кількісних показників повноцінності захисту міокарда в умовах штучного кровообігу, у тому числі досліджень розподілу температури на поверхні міокарда, що дозволяє значно підвищити ефективність захисту серця в умовах штучного кровообігу від факторів ішемічних ушкоджень міокарда.

\section{ПЕРЕЛІК ПОСИЛАНЬ}

[1] Кузнецов С. В., Давыденко В. В., Мочалов О. Ю., Дойников Д. Н., Лапшин А. С., Грицаенко Д. П. Защита миокарда при операциях на “открытом” сердце / Под редакцией доктора медицинских наук, профессора В. В. Гриценко / Санкт-Петербург: СПбГМУ им. акад. И. П. Павлова. 2009. - c. 42

[2] Kirklin J. W., Barratt-Boyes B. G. Myocardial management during cardiac surgery with cardiopulmonary bypass // Kirklin J. W., Barratt-Boyes B. G. Cardiac surgery. - 2-nd ed. - New York: Churchill Livingstone Ins, 1993. Ch.3. - P.129-167.

[3] Локшин Л. С, Лурье Г. О., Дементьева И. И. Защита миокарда при операциях на открытом сердце / Локшин Л. С, Лурье Г. О., Дементьева И. И. Искусственное и вспомогательное кровообращение в сердечно-сосудистой хирургии: Практическое пособие. - Москва, 1998. - Гл. 7. C. $120-131$. 
[4] Кузнецов С. В., Гриценко В. В., Дойников Д. Н. Сравнительная оценка миокардиальной протекции холодовой и тепловатой кровяной кардиоплегии при операциях на открытом сердце // С. В. Кузнецов, В. В. Гриценко, Д. Н. Дойников и др.// Достижения и перспективы хирургии в СПбГМУ 2008. - С $38-40$.

[5] Mentzer R. Mi Jr, Jahania M. Si, Lasley R. Di Myocardial Protection. Cohn Lh, ed. Cardiac Surgery in the Adult. New York: McGraw-Hill, 2008: 443 - 464.

[6] Buckberg G. D., Brazier J. R., Nelson R. L., et al. Studies of the effects of hypothermia on regional myocardial blood flow and metabolism during cardiopulmonary bypass. I. The adequately perfused beating, fibrillating, and arrested heart. J Thorac Cardiovasc Surg 1977; 73: 87 - 94.

[7] Gravlee G. P., Davis R.F., Kurusz M., Utley J. R. Cardiopulmonary Bypass: Principles and Practice, 2nd ed. Philadelphia, Lippincott Williams \& Wilkins, 2000.

[8] Максименко В. Б. Кардиоанестезиология, искусственное кровообращение, защита миокарда.// В. Б. Максименко и др. Киев. 2007. - С. 241.

[9] Hayashida N., Ikonomidis J. S., Weisel R. D., et al. The optimal cardioplegic temperature. Ann Thorac Surg 1994; 58: 961-971.

[10] Муравйов О. В., Назарчук О. О., Шликов В. В., Максименко В.Б.Світлосильний атермалізований об'єктив для інфрачервоної області спектра. Патент на корисну модель №118184, 25.07.2017, бюл. №14, заявка u201701404 від 14.02.2017 URL: http://base.uipv.org/searchINV/ getdocument.php?claimnumber $=\mathrm{u} 201701404 \&$ doctype $=\mathrm{ou}$

[11] Максименко В. Б., Шлыков В. В., Данилова В. А. Отображение тепловых неоднородностей для последовательности изображений в видео термограмм / Вісник Національного технічного університету "ХПІ": збірник наукових праць Сер.: Механіко-технологічні системи та комплекси. - Харків: НТУ "ХПІ", 2017. - № 19 (1241). C. 42-47. - URL: http://mtsc.khpi.edu.ua/article/view/108075/ 108075-229239-1-PB.pdf

[12] Шлыков В. В., Данилова В. А. Метод оценки скорости охлаждения и согревания сердца в условиях искусственного кровообращения // Наукові вісті НТУУ "КПІ", No 6(116) (2017). C. 47-52. - URL: http://bulletin.kpi.ua/ article/download/96276/pdf_279. 


\title{
ЗАЩИТА МИОКАРДА ПРИ ОПЕРАЦИЯХ НА ОТКРЫТОМ СЕРДЦЕ
}

\author{
Шлыков В. В., доц., к.Т.н. \\ v.shlykov@kpi.ua \\ Факультет биомедицинской инженерии \\ Национальный технический университет Украины \\ «Киевский политехнический институт имени Игоря Сикорского» \\ г. Киев, Украина
}

Реферат - Метод гипотермической защиты миокарда занимает важное место при коррекции неосложненных пороков сердия, а угнетение метаболизма и снижение потребностей миокарда в кислороде при низкой температуре является основным кардиопротекторным фактором, который обеспечивает защиту миокарда в условиях искусственного кровообращения. В данной статье описаны существующие методы защиты миокарда и интегральные показатели для полноценной защиты миокарда при операциях на открытом сердие. Представленные температурные характеристики миокарда и факторы, определяющие степень ишемических повреждений миокарда при гипотермии сердиа. Предложен способ неинвазивного измерения температуры сердия в условиях искусственного кровообращения. Для оценки данных изменения температуры на поверхности миокарда в условиях искусственного кровообращения предлагается использовать термографические камеры, которые работают в диапазоне частот 7,5-13 мкм и имеют температурную чувствительность не ниже $0,5^{\circ} \mathrm{C}$.

Ключевые слова - защита миокарда, гипотермия, искусственное кровообращение, термография, распределение температуры. 
UDC 616.21-615.015.12

\title{
THE MYOCARDIUM PROTECTION AT THE OPERATING ON OPEN HEART
}

Shlykov V. V., Associate Professor, Ph.D. v.shlykov@kpi.ua

Faculty of Biomedical Engineering National Technical University of Ukraine «Igor Sikorsky Kyiv Polytechnic Institute»

Kyiv, Ukraine

\begin{abstract}
Purpose. The method of hypothermic protection of the myocardium plays an important role in the correction of uncomplicated heart disease, and the inhibition of metabolism and reduction of myocardial oxygen demand at low temperature is the main cardio protective factor that provides protection of the myocardium in conditions of cardiopulmonary bypass. The existing methods of protecting the myocardium and integral indicators for the full protection of the myocardium during open heart surgery are described. The temperature characteristics of the myocardium and factors that determine the degree of ischemic damage to the myocardium during hypothermia of the heart are presented. The method in cardiology of non-invasive measurement of heart temperature in cardiology in conditions of cardiopulmonary bypass is proposed. For estimate the change in temperature on the surface of the myocardium in conditions of cardiopulmonary bypass, it is proposed to use thermographic cameras that operate in the frequency range of 7,5-13 microns and have a temperature sensitivity of not less than $0,5^{\circ} \mathrm{C}$.

Keywords - protections of the myocardium, hypothermia, cardiopulmonary bypass, thermography, temperature distribution.
\end{abstract}

